\title{
DESEGREGATING URBAN SCHOOLS
}

\section{A Causal Perspective}

\author{
DAVID R. MORGAN \\ University of Oklahoma \\ MICHAEL R. FITZGERALD \\ University of Tennessee
}

Two models of desegregation change between 1968 and 1974 for a number of U.S. urban school districts are tested using a block-recursive technique incorporating the effects of community environment, the school system, and federal influence. The models can explain a considerable amount of change in the North but much less in the South. In both regions, federal intervention is a dominant influence, although for one model in the North, the earlier year level of desegregation is the most powerful effect.

Schools in this country continue to desegregate, especially in the South. In fact, the desegregation gap between North and South has actually widened in recent years. Southern school districts, once the most highly segregated in the country, are now the most integrated. This enormous change has been widely attributed to actions of $\mathrm{HEW}$ and the federal courts. Rightly so in many places. But among 1300 districts recently surveyed by the U.S. Commission on Civil Rights (1976), about $37 \%$ of those that had desegregated did so under state or local initiative. Hence, explaining desegregation change by referring to only federal pressure is not sufficient. In addition, federal help to districts undergoing desegregation efforts should be included as a force potentially contributing to more rapid change in school segregation levels.

Authors ${ }^{\circ}$ Note: This study was made possible, in part, by a grant from the Research Council of the Graduate School, University of Missouri-Columbia. We are grateful to our colleague, Kenneth Meier of the University of Oklahoma, for his methodological . assistance in our work. We are also indebted to Duane Richards, Matt Saunders, and Barry Trautman for their data-gathering efforts on our behalf. 
And finally, other community-level forces in addition to the federal government surely must be taken into account in explaining variation in the rate of school desegregation change around the country.

The analysis presented here attempts to sort out the various forces contributing to desegregation change between 1968 and 1974 among a large group of U.S. cities. Using northern and southern communities, we are especially interested in the following issues. First, are those forces associated with urban school desegregation in the mid-sixties the same ones that have produced desegregation change over the past decade? Second, to what extent have the characteristics of the school system itself facilitated or inhibited desegregation change? A growing body of research suggests that the contribution to desegregation efforts by school and community leadership cannot be ignored. Third, what about federal involvement? Should we not examine both the coercive and facilitative actions of the national government? Fourth, we think sufficient evidence regarding forces affecting school desegregation has been gathered that now it may be possible to develop more parsimonious explanatory schemes for this purpose. Finally, we think more valid policy inferences can be made regarding the dynamics of urban school desegregation by focusing on levels of change over time.

\section{PREVIOUS EFFORTS TO EXPLAIN DESEGREGATION}

Most previous research has concentrated on explaining levels of desegregation for a single time period-understandably so. School desegregation as a conscious government policy has been underway a relatively brief time. Even so, a good deal of information has been accumulated regarding those forces affecting the desegregation process.

First, earlier research has documented that apart from federal involvement, three community-level influences affect school desegregation above all others: (1) the proportion of black 
students in public schools (Dye, 1968; Farley, 1975); (2) the size of the school district (Giles, 1975; Giles and Walker, 1975; Farley, 1975; Coleman, 1976); and (3) residential segregation (Farley, 1975; Taeuber, 1979). The more blacks present and the larger the district, the more difficult it has been to secure desegregation. Apparently the majority of the population is more threatened by integration where the proportion of minority students within a school district is large. For example, Giles and associates (1975; also see Cataldo, 1975) report that white exodus from public schools accelerates when the minority population exceeds around $30 \%$. We should note, however, that as federal intervention occurs the percentage of black pupils in a district becomes considerably less important as an influence on southern school desegregation (Giles, 1975; Fitzgerald and Morgan, 1977). Larger districts impede desegregation, apparently for logistical reasons. The more students must be moved about, the harder it is to produce the desired level of desegregation. Finally, under the neighborhood school concept so popular in this country, if no residential segregation were present, perhaps there would be no need to desegregate schools at all.

As suggested above, the school system is not merely a neutral vehicle in the desegregation process. A recent U.S. Commission on Civil Rights report (1976: 128-132) emphasizes the importance of school administration and community leadership in promoting desegregation among a select group of 29 cities. Others (Rodgers and Bullock, 1976: 40-45) confirm this view. In particular we might expect school boards that are most insulated or protected from immediate community pressure to acquiesce more readily to desegregation plans initiated by outside parties. Some (Crain et al., 1969; Kirby et al., 1973) believe that where sensitive or socalled "fragile" issues are under consideration, action by local governments is easier where public participation is minimized. Cities with more centralized political leadership, for example, more readily implemented water fluoridation decisions. The same logic would seem to hold for such a potentially explosive issue as school desegregation. In addition to the school board, the superintendent can play a potentially decisive role (Kirby and 
Crain, 1974). Rodgers and Bullock (1976: 44) find superintendent longevity to be inversely related to desegregation success among their southern communities. Apparently, bringing in new administrative leadership can hasten the process of desegregation.

Finally, and in some ways of greatest interest, the impact of the federal government must be considered. Federal involvement comes in two forms. Most dramatically, the Justice Department can bring suit. And, of course, HEW may compel districts to comply with various desegregation plans. Both of these can be considered appropriately as federal coercion. Rodgers and Bullock (1976: 40) offer evidence that in the South, at least, major change would not have occurred without such pressure. But, less widely known, the federal government also provides inducements in the way of technical and financial assistance to desegregating districts. This form of federal activity should also be considered in evaluating the effectiveness of the total federal effort to get schools to desegregate.

As discussed above, most previous research has concentrated on explaining the level of desegregation for a single time period. But with the passing of each year (and the collection of more data by the Office of Civil Rights), it becomes possible to focus on changes in desegregation over time. The basic question, of course, is the extent to which those forces apparently responsible for desegregation in a given year also shape desegregation change. The community context, the school system, and the federal government seem to be the prime determinants of desegregation cross-sectionally. We think these same forces will affect the change process as well and should be considered as taking place in a sequential order. That is, logically we might assume that certain community or school district conditions largely set the basic parameters in which segregation levels were allowed to develop. Previous research suggests the most important community environmental forces are the percentage of black students in the district, district size, and residential segregation. As the legal situation slowly changed following the Brown decision in the mid-fifties, school boards and superintendents became more directly involved in deciding how to respond to the growing 
realization that the federal government meant business. Finally, the federal government actively entered the picture in many communities either by coercing cities to comply and/or providing financial assistance for desegregation plans. In brief, we think the process can best be conceptualized in the following sequence: (1) the community environment establishes the basic level of segregation that may lead to a response on the part of school officials and the federal government; (2) school officials react either to coercion or positive incentives from the federal government; and (3) the federal government eventually takes steps positively and/or negatively to secure compliance.

We realize, of course, that this process seems more characteristic of what has happened in the South than in the North. But we believe the applicability of this scheme should be tested in the North as well. Therefore, in the analysis to follow we offer separate models by region to test the assumptions discussed above.

The existence of school desegregation data over time permits us to do some additional analysis that may help shed further light on those influences affecting more recent levels of desegregation. For example, if one wants to explain 1974 desegregation among a group of communities, certain information might be used that was not available for earlier desegregation studies. We are referring to the level of segregation existing at an earlier time, say in 1968. Perhaps those districts that remain highly segregated in 1974 are largely the same group that were prominently segregated six years earlier. If this is so, we might conceive of the 1968 desegregation level as acting as a surrogate for the various community context variables in our analysis. That is, perhaps we should consider the environmental pressures as operating initially on 1968 desegregation, which in turn affects 1974 levels. Although this conceptualization does not employ a change measure as a dependent variable, it nonetheless might be thought of as representing another way of assessing how the desegregation process changes over time.' The analysis to follow will thus test this additional assumption, using 1968 as the base level of desegregation and the 1974 level of desegregation as the final dependent variable. 


\section{DATA AND METHODS}

The independent variables to be used in the analysis are operationalized as follows:

Community Environment ${ }^{2}$

(1) School district size. The natural log transformation of total student enrollment in 1968 (U.S. Department of Health, Education, and Welfare, 1970).

(2) Percentage black enrollment. The proportion black of total district enrollment for 1968 (U.S. Department of Health, Education, and Welfare, 1970).

(3) Residential segregation. The index of dissimilarity between the distribution of white and nonwhite households among city blacks; the Taeuber index (Sorenson et al., 1975).

1968 Base School Segregation Level

(4) 1968 segregation. Measured by the index of dissimilarity (Taeuber and Taeuber, 1965).

School System

(5) School board insulation. Represents certain structural features that should tend to minimize direct community influence derived by summing the following for each board (one point assigned for presence of each attribute): appointed or nonpartisan elections if not appointed; board term in excess of four years; meetings scheduled less than twice a month; board composed of less than seven members (survey conducted by authors). Range is $0-4$.

(6) Superintendent longevity. Measured as the number of years the superintendent in 1974 has been employed by that particular district (Elliot, 1964-1974).

Federal Intervention ${ }^{3}$

(7) Coercive. A three-point index that sums: (1) action by HEW, Office of Civil Rights (OCR), under Title VI, 1964 Civil Rights Act (CRA) that could (or did) result in termination of all federal monetary assistance for noncompliance with desegregation guidelines (1964-1972); ${ }^{4}$ (2) Department of Justice legal action against districts under Titles IV and IX, 1964 CRA (1964-1974); federal court action to implement Supreme Court's Brown decision (1964-1974). 
(8) Noncoercive. A three-point index that sums: (1) Department of Justice, Community Relations Service Action under Title X, 1964 CRA to provide assistance to resolve school desegregation disputes (as of 1972); (2) Office of Education grants under Title IV, 1964 CRA for technical assistance to aid school desegregation (1964-1972); (3) Office of Education grants under Emergency School Aid Program (ESAP.) and Emergency School Aid Act (ESAA) of 1972 (as of 1972). ${ }^{5}$

The first dependent variable, desegregation change, is operationalized as the residual when 1974 desegregation levels (the Taeuber index of dissimilarity) ${ }^{6}$ are regressed on 1968 levels for each urban school district within each region. The Taeuber index has been reversed by subtracting from one so that high values reflect more desegregated schools. This measure of change, which predicts 1974 desegregation using 1968 data, is independent of values at time one. This method is especially appropriate as opposed to the customary percentage change measure where considerable variation exists in the initial values at $t$, (Van Meter, 1974).

The data come from 103 U.S. cities in both North and South ${ }^{7}$ with a population of at least 50,000 in 1960 and 1970, and in which at least $3 \%$ of the students in public schools are black. The basic unit of analysis is the principal local public school district serving each of these cities. Data on racial enrollment for the districts are taken from the U.S. Department of Health, Education, and Welfare $(1976,1970)$ national surveys taken in 1968 and 1974.

The sequential model outlined above will be tested by employing a modification of a block-recursive technique suggested by Sullivan (1971). This procedure permits the researcher to use multiple indicators while retaining a relatively small group of predictor variables. As implied by our previous discussion, we think the incorporation of several categories of explanatory variables is essential. At the same time, however, we do not wish to imply causality among the separate variables belonging to each class. For example, we want to include the effects of both district size and proportion of black students. But we cannot think of any plausible reason why one should be thought to "cause" the other. 
Likewise, we need to use a pair of school system characteristics, again without positing any causal sequence between the two. Thus we end up with a relationship, which we think preceeds in temporal order, among a block of variables, each representing the environment, the school system, federal activity, and desegregation change.

Our block-recursive system requires the calculation of multiple-partial correlation coefficients in sequential order. First, we will derive multiple partials for each of the two sets of communitylevel variables, using federal intervention (both coercive and noncoercive) as the dependent variables. Then we will calculate multiple partials between the environment and desegregation change, holding out the effects of the school system and federal activity. Next we include school system with desegregation, controlling for the community context and federal presence. Finally, the direct effect of federal influence is derived by holding constant all antecedent independent variables. In calculating multiple-partial effects, we make a slight change in the traditional formula offered by Blalock (1972: 459). For example, to calculate the effects between variable 1 (dependent) and block 2 , controlling for blocks 3 and $4\left(\mathrm{r}_{1(2) \cdot 34}^{2}\right)$, we normally have the formula

$$
r_{1(2) \cdot 34}^{2}=\frac{R_{1 \cdot 234}^{2}-R_{1 \cdot 34}^{2}}{1-R_{1 \cdot 34}^{2}}
$$

The numerator in this expression represents the proportion of variance explained by variable 2 when the effects of 3 and 4 are held constant. Blalock then indicates that to work on only that variation left unexplained by the control, the quantity must be divided by $1-R_{1 \cdot 34}^{2}$. But when this is done, the denominator for each multiple-partial equation will vary. Strictly speaking, this means we cannot compare the resulting coefficients. But, in fact, we do need to compare the relative strength of coefficients in the model. Accordingly, we think it preferable to drop the denominators from the equations and use only the amount of variation remaining when the multiple coefficient being held constant (in our example, $\mathrm{R}_{1: 34}^{2}$ ) is subtracted from the total explained vari- 
ance $\left(\mathrm{R}_{1 \cdot 234}^{2}\right)$. This yields the variance attributable only to the effects of variable 2 on 1 . Such a procedure is actually comparable to the notion of additions to $\mathrm{R}^{2}$, which is commonly used to calculate the effects of including additional variables in a multiple regression model.

\section{FINDINGS}

The means, standard deviations, and simple correlation coefficients for the urban school districts are reported by region in Table 1. As compared to their northern counterparts, urban districts in the South are, on the average, slightly larger in proportion of black enrollment. Average district size is identical between regions. Superintendent tenure is virtually the same for the two groups, while southern school boards are slightly less insulated than their northern counterparts. The most striking regional difference is the average level of federal intervention on behalf of school desegregation. Given the history of desegregation policy development and implementation, with its traditionally southern focus, it is no surprise to find that cities in that region bore the brunt of more federal coercion and received more federal assistance than northern urban districts. Although more federal intervention (especially in the form of district court orders) occurs as time passes, this activity is still aimed predominantly at southern cities.

Since the means for desegregation change approach zero in both regions (because of the residualizing procedure), they provide little descriptive sense as to desegregation shifts during the period. A clearer picture of such changes emerges from examination of the average Taeuber index values for each year, 1968 through 1974. These show that, although northern districts were initially more desegregated, by 1972 their average fell behind that of the southern school systems. By 1974 the South had even further improved its newly acquired desegregation process advantage. Thus, by 1974, about half of the students from these urban districts in both regions attended public schools that, according to the Taeuber index, were considered desegregated. 


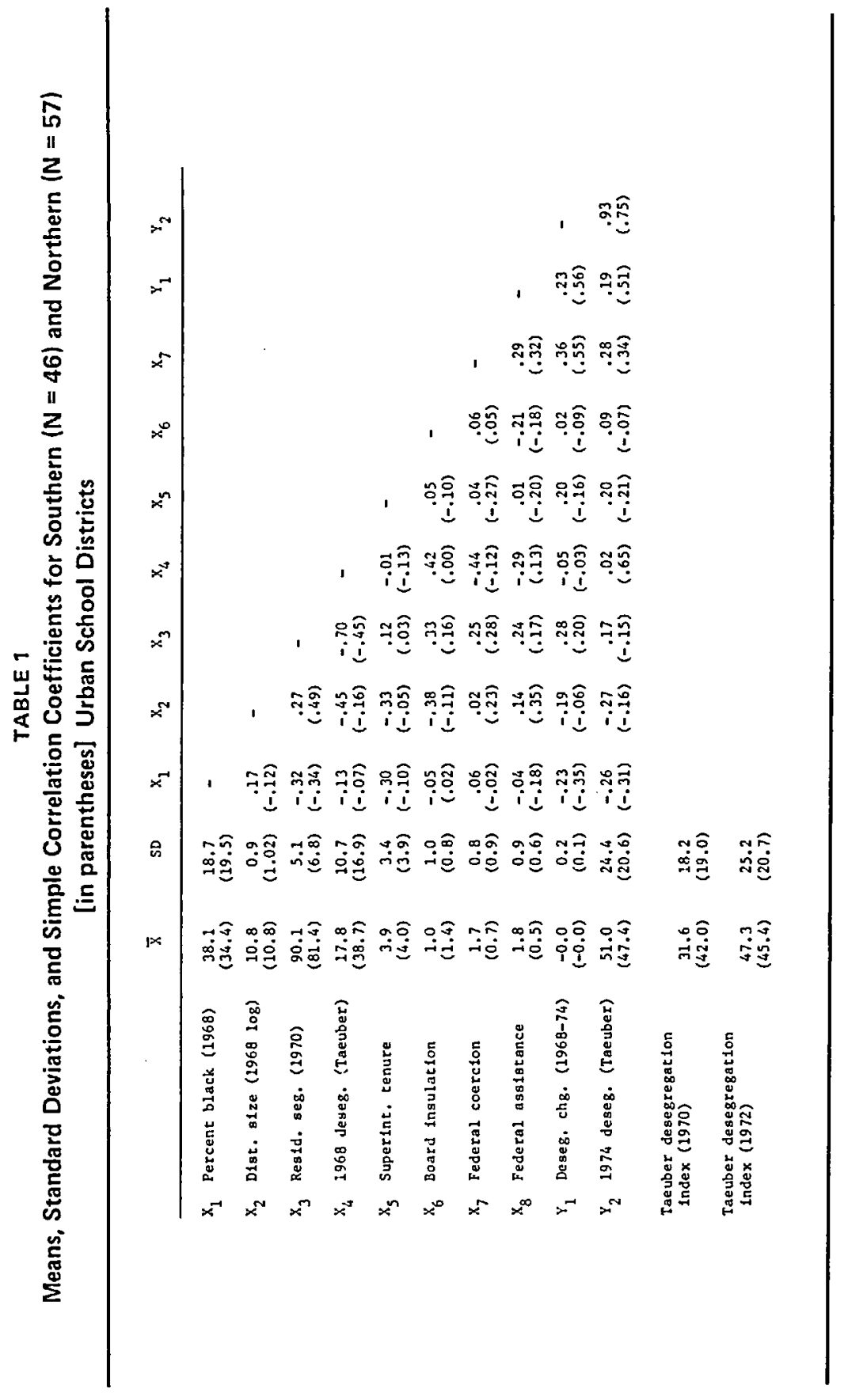


Rodgers and Bullock (1976: 34) estimate that a desegregation score approaching .80 represents a realistic Taeuber figure for considering any school district completely desegregated. By this criterion, both regions continue to fall short of entirely successful desegregation, although the trend reflects improvement.

We hypothesized that substantial relative black enrollments, more extensive district size, and residential segregation, while perhaps diminishing in effect, remain of sufficient negative influence to require relatively greater federal intervention in behalf of school desegregation. We further posited that extended superintendent tenure would constitute a desegregation barrier also leading to greater federal desegregation acitivity - as would the presence of a school board relatively less insulated from antidesegregation sentiments in the community. In short, we expect to find that federal penetration should be more prominent where substantial "natural" community barriers to desegregation exist. Federal intervention, of course, should yield more substantial desegregation progress. Operationally, this chain of effects is initially tested by the block-recursive system depicted in Figure 1. To be sure, it is unrealistic to expect that this very simple model of such a complex process can attain a very high level of predictive power. Yet, by specifying certain salient factors and emphasizing a certain order of cause and effect, we hope to cast additional light on this vital policy area.

The explicit causal sequence presented is a simple one: Environmental and school system constraints on desegregation elicit federal activity in response, and this intervention produces greater change. The coefficients reported between each block of variables in Figure 1 are multiple partials (modified). ${ }^{8}$ They indicate each block's predictive power on the block to its right in the model, when the effect of the other blocks are held constant statistically. Figure 1 also presents the coefficients of multiple determination for federal intervention (block 4) and desegrega-

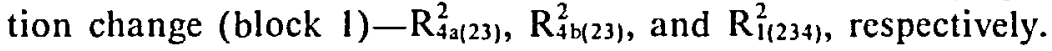
These values estimate the predictive power of blocks 2 and 3 on block 4 (intervention) and blocks 2,3 , and 4 as they predict block 1 (change). 


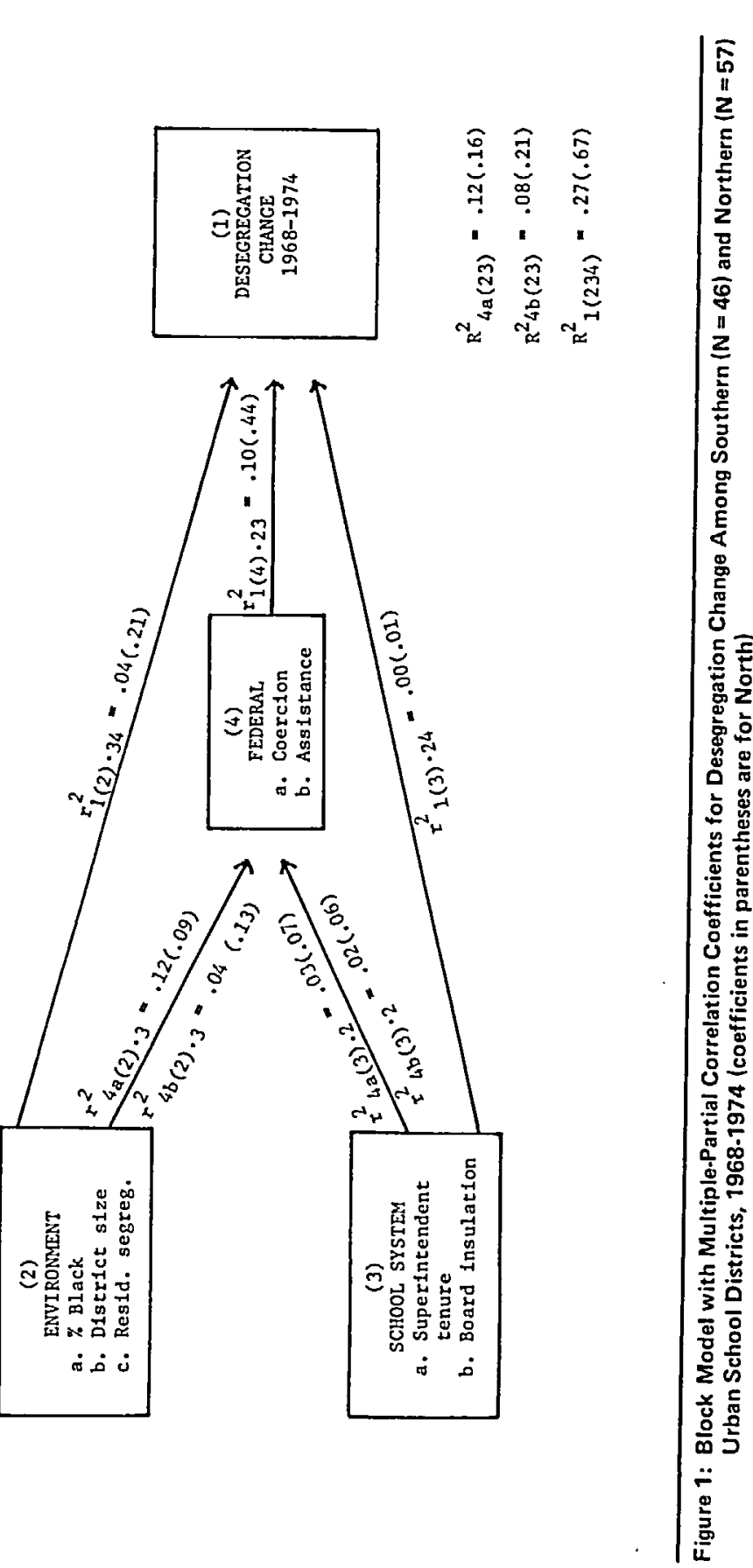


The predictive power of the southern block model is disappointing indeed. Together, the environmental and school system blocks explain only $12 \%$ of the variance in federal coercion and $8 \%$ of the variance in federal assistance among the urban districts of the region. Although more substantial than in the South, the $16 \%$ (coercion) and $21 \%$ (noncoercion) of variance in intervention accounted for by these blocks in northern districts are hardly impressive figures. In South and North alike, the multiple partials show that, with respect to both forms of federal intervention, the environmental block carries greater explanatory weight than that of the school system (see also Wegner and Mercer, 1975). Obviously, the preliminary stages of the models are insufficient as an explanation of federal intervention levels among the urban districts.

The southern block model again proves disappointing in accounting for levels of desegregation change. The three blocks cumulatively account for only $27 \%$ of the variance in the final dependent variable for urban districts in the South. As hypothesized, the strongest predictor in the South is federal intervention, explaining statistically $10 \%$ of the variance in change levels. The school board block, in contrast, contributes nothing directly to explained variance. Here we might also observe that efforts to account for a dependent variable measured as a change ratio are frequently disappointing unless a lagged dependent variable is used in the regression equation (contrast, for example, Asher and Van Meter, 1973; Gray, 1973).

The results for northern communities are considerably more satisfactory: The cumulative effect of the environmental, school system, and intervention blocks can statistically account for twothirds of the variation in desegregation change in this region. This preponderance of predictive power for the total northern model rests with the federal intervention block, which alone accounts for $44 \%$ of change differences in these districts. Again, school system measures are virtually inconsequential in directly predicting desegregation change.

In both southern and northern districts, the community environment shows some measurable effect on urban desegrega- 
tion change levels. This influence, which is quite limited nonetheless, appears to be only partly transmitted through federal intervention as such, since this block accounts for so little variation in the federal intervention block. Clearly, federal action (especially in northern districts) emerges as the major influence on urban desegregation change.

Now let us consider what happens when we add base level desegregation (1968) in a similar block-recursive model to explain the 1974 level of desegregation (see Figure 2). First we might note the relationship between the desegregation measures for the two time periods (see Table 1). In the South, as expected, the two are almost totally unrelated $(r-.02)$, but for northern cities, 1968 and 1974 desegregation are substantially correlated at $.65 .^{9}$ For the model itself, the two initial blocks (community environment and school system) explain a large proportion of 1968 desegregation levels for southern districts $\left(\mathrm{R}^{2}=.68\right)$. By 1974 , however, all the blocks can account for only $26 \%$ of southern desegregation. Parenthetically, this level of explained variance for 1974 in the South is almost identical with that found for desegregation change. The greatly diminished impact of the two initial blocks on 1974 desegregation in the South clearly reveals the degree to which other-than-local forces now shape the progress of desegregation in that region.

The effects of the environment and the school system on federal intervention shown in Figure 2 are identical with those in Figure 1. We might observe, however, that the school block bears very little relationship to the base desegregation level (1968).

Returning again to the final dependent variable, a substantial gain in explanatory power has been achieved for northern cities between 1968 and $1974\left(R^{2}=.29\right.$ to $\left.R^{2}=.81\right)$, a pattern just opposite to that in the South. The reasons for this are not difficult to discern. Many of the northern districts that were conspicuously segregated at the earlier period remain so six years later, although when other variables are controlled, 1968 desegregation can predict only $25 \%$ of the variance in 1974 levels. Federal intervention proves surprisingly strong as well. But why was explained 


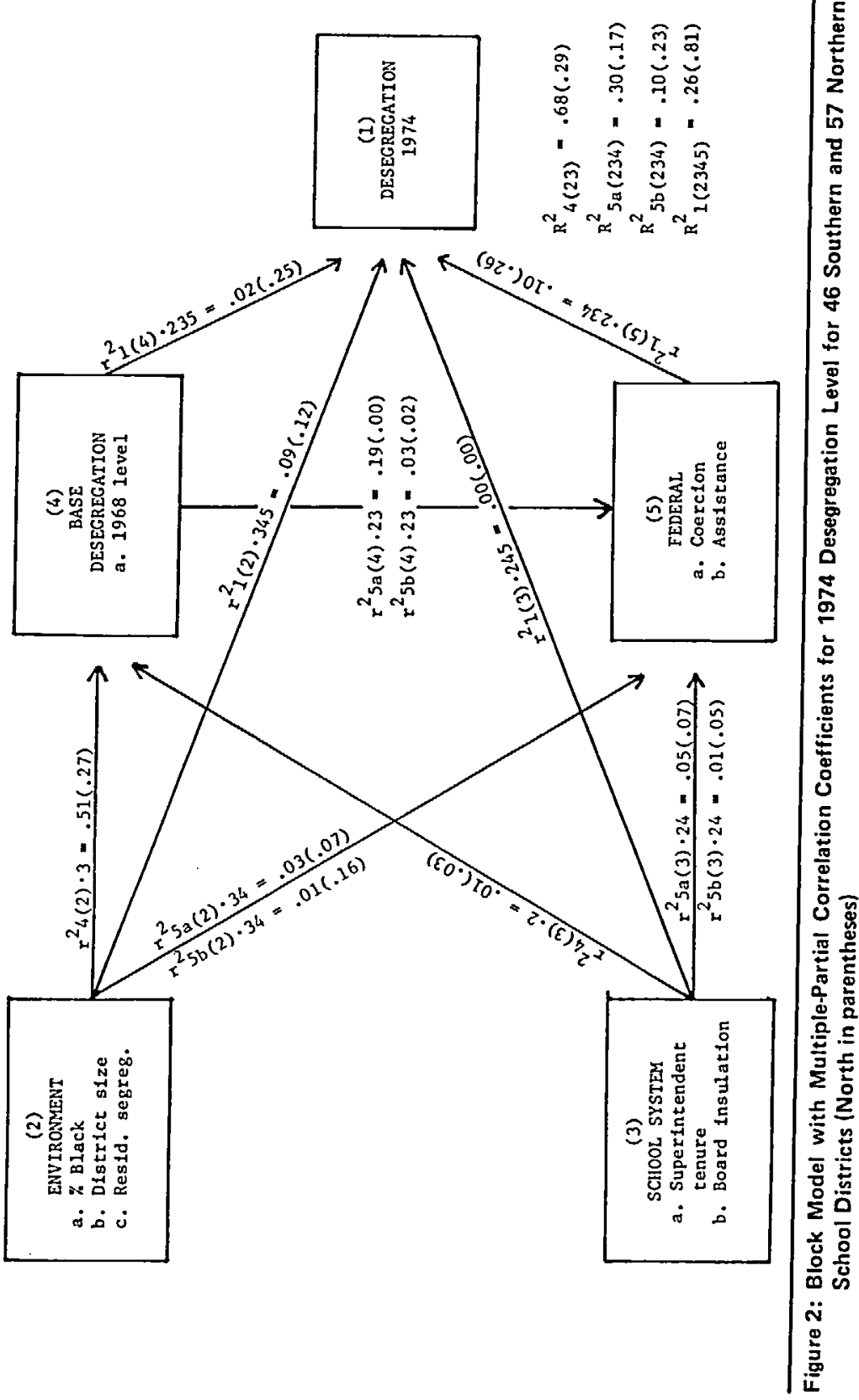


variance so low for the North in 1968 ? The answer lies mostly in the lack of potency for the environmental variables. For the earlier period, desegregation in the North was not as closely tied to the community context as it was in the South. For example, residential segregation (1970) and 1968 desegregation in the North are correlated at only -.34 , but the two reach a magnitude of -.70 for southern cities. Thus, our capacity to predict northern desegregation levels for 1974 has been substantially improved by the presence of the federal government ${ }^{10}$ and the pass-through effect of the desegregation base for 1968.

Now, what about the South; why does explained variance drop so drastically from 1968 to 1974? Again the answer is fairly straightforward. In the earlier period, school desegregation was heavily dependent on local environmental forces. Explained variance for 1968 is thus quite high $\left(\mathrm{R}^{2}=.68\right)$. But as federal intrusion became increasingly salient, these environmental influences virtually disappear, and variance explained diminishes substantially $\left(R^{2}=.26\right)$. The only surprising thing here is the lack of explanatory power for the two measures of federal intervention. We had expected that as environmental impact decreased, a compensating level of explanation would result from the measures of federal influence. Why this failed to happen is not clear. We admit that our indices of federal penetration are not as inclusive as we would like, although they do incorporate virtually all the federal desegregation activity that gets officially recorded." Still, something must be missing. Beyond the inadequacies of our federal variables, all we might suggest is that the process in the South was still in a state of flux during the six-year period, and settled patterns have been slower to appear than had been expected.

\section{CONCLUSION}

Changes in urban school desegregation have been considered from two different perspectives. A measure of change from 1968 to 1974 was analyzed along with the absolute level of 
desegregation for 1974, which was the dependent variable in an equation that included the 1968 level of segregation as an explanatory measure. Where the change measure was involved, we found, using a block-recursive model, that traditional barriers to school desegregation (relative black presence, school district size, and residential segregation) continue to give way in the face of federal coercion as well as federal assistance. Surprisingly, federal intervention was a more powerful explanatory factor for the northern model, in contrast with the South. Community forces continue to exert a noticeable influence in the North, as well. Although federal intrusion was also the most important force affecting the southern cities, the effort to model desegregation change did not work well for the South.

When the 1968 base level of desegregation was included along with the other blocks to analyze the level of desegregation for 1974, substantially different results were obtained for the two regions. Primarily because of the pass-through effects of base desegregation and the impact of federal intervention, this model could account for over $80 \%$ of 1974 desegregation among the 57 northern cities. But, just as for the change model, the analysis of 1974 desegregation for the 46 cities of the South was disappointing $\left(\mathrm{R}^{2}=.26\right)$. So, from either perspective, it has become increasingly difficult to explain the process of desegregating southern schools.

The failure to account for change in the South may well be indicative of a general development pattern in southern urban desegregation. Once the "easy" initial desegregation in urban districts has been achieved - the kind that results from the mere presence of federal pressure or even the threat of such intervention-progress may become more dependent on the type and quality of intervention involved. The comparatively less powerful effect of federal intervention in the South may be the result of a confrontation with a more intransigent segregation mode-a hard-core, de facto, uniquely urban brand. To the extent this is so, federal influence thus encounters environments possessed of substantial political resources at both the state and national levels. Such areas may be able to resist and delay all but the most 
coercive and dedicated desegregation pressures (something typically lacking in the federal executive under the Nixon-Ford administrations). If this is true, then measures of intervention far more exact than the sources operationalized in the present study will be needed to explain desegregation change. In addition, the federal measures may have been less obtrusive than expected, because virtually every southern district by 1974 was experiencing some type of enforcement. Such a wide-spread effort not only diffuses federal resources but reduces the variation in the enforcement measure itself, which may lessen its predictive power.

Once a community, with federal assistance, has initially overcome the triple barriers of black presence, district size, and residential segregation, we suspect that the variation among cities in desegregation progress also becomes more dependent on differences in socioeconomic and political characteristics too subtle to be captured accurately in broad census categories. Most especially, we suspect that the quality rather than the quantity of relevant community forces will become increasingly critical: the nature of the community's desegregation plan, the effectiveness of black and white leadership, the skills of teachers and administration, and so on. Future modeling of desegregation must consciously strive to improve the measurement of such qualitative characteristics if it is to explain successfully this controversial process.

\section{NOTES}

1. It might seem that the 1968 base desegregation variable could merely be employed in the analysis of change. Certain difficulties arise if this is done, however. First, the way in which the measure of change is operationalized, as a residual when 1974 levels $\left(t_{2}\right)$ are regressed on 1968 levels $\left(t_{1}\right)$, forces the change measure to be independent of the values at $t_{1}$. Second, if the change measure is operationalized differently, say as a percentage change, we encounter the problem of extreme variation in the dependent variable, an undesirable effect that the residualized change measure is specifically designed to avoid. Thus we reluctantly concluded that two separate analyses were necessary, one in which change is explicitly used as a dependent variable and one in which we test the thesis that more recent levels of change may be largely a function of earlier levels of school segregation. 
2. We recognize that by operationalizing the community environment with only three variables (district size, percentage of black students, and residential segregation), we are omitting several measures that may also affect the desegregation process. For example, in previous research (1977) using 1968 and 1972 desegregation measures, we found the following socioeconomic and political variables to be statistically significant in either North or South for at least two equations: local power centralization (MPO ratio), vote for Wallace for President (1968), and city-operated school system. None of these, however, were as consistently powerful as the three community environment indicators chosen. For the sake of parsimony and greater methodological elegance, we think it justified to drop these additional variables. This permits us to concentrate on the relational sequence of a limited group of variables discussed above.

3. These measures come from the U.S. Commission on Civil Rights (1973) and unpublished data from the Department of Health, Education, and Welfare, Office of Education, Program Services Branch, Bureau of Equal Education Opportunity made available by Ms. Rosalie Spence. The updated court order data were taken from the 1974 HEW survey.

4. The minimal action by HEW involved here was citation of the district for noncompliance with the 1964 Civil Rights Act. If, at later administrative hearings, noncompliance was established, the school system could be denied all federal funds until. compliance was achieved.

5. The ESAP and ESAA programs provide federal funds to school districts to meet additional costs of new or expanded activities necessary to implement desegregation plans and achieve desegregation. Although the ESAP I and II programs were directed largely toward southern school systems, communities in nine nonsouthern states received ESAP grants: California, Colorado, Illinois, Indiana, Kansas, Michigan, New Jersey, Pennsylvania, and West Virginia (U.S. Department of Health, Education, and Welfare, 1972: Tables III, V, and VIII). In contrast, ESAA grants in the first fiscal year of the program were geographically distributed in a wider fashion: Communities in all but seven nonsouthern states received ESAA funds (U.S. Department of Health, Education, and Welfare, 1973: Appendix A).

For the period under study federal coercive and noncoercive activitics were directed toward southern school districts. A comparison of the percentage of our cities receiving such federal pressure or assistance (northern communities in parentheses) reveals the clear maldistribution:

\section{COERCIVE}

$\begin{array}{ll}\text { HEW Title VI } & 17.5(7.0) \\ \text { DJ Title IV and IX } & 77.5(25.4) \\ \text { Court Order } & 82.5(20.2)\end{array}$

\section{NONCOERCIVE}

$\begin{array}{ll}\text { DJ Title X } & 46.3(0.0) \\ \text { HEW Title IV } & 55.0(30.7) \\ \text { ESAP I and II } & 77.5(7.9)\end{array}$

It is clear that, while southern cities received a larger share of such federal activities, such receipt was by no means universal in that region. Similarly, receipt of federal pressure or assistance of some type was by no means unknown in the North. A comparison of regional 
means and standard deviations confirms the presence of variation within the North and South, as well (northern cities in parentheses):

$\begin{array}{lcc} & \text { Mean } & \text { SD } \\ \text { COERCIVE } & 1.8(.5) & .8(.9) \\ \text { NONCOERCIVE } & 1.8(.4) & .9(.6)\end{array}$

Thus, in both regions there was some variation in federal activities of both the coercive and nonconcersive type. It seems reasonable to expect, therefore, that variation in these scales will help explain variation in desegregation levels within each region.

6. The index of dissimilarity for school desegregation in the application of a measure developed by Taeuber and Taeuber (I965) to assess residential segregation. It represents the amount by which each school in a district departs from the precise racial composition of the entire district. We have modified the Taeuber index to reflect desegregation rather than segregation levels. Thus, for this study, we have:

\section{$D=1-(1 / 2$ sum of absolute value of Blacks in School/ Blacks in District - Whites in School/Whites in District).}

The index is an absolute measure that ranges from zero, where every school mirrors the district racial balance, to 1.00 , indicating that every school within the district is totally desegregated. In our earlier work we employed a desegregation measure that some argue better represents the political realities surrounding the desegregation process than does the Taeuber index. Nonetheless, the Taeuber index continues to be the most widely used measure by far. Thus, in the interests of making our findings more congruent with most of the other work in this area, we decided to use the Taeuber measure in this analysis. For a discussion of the differences among several measures of desegregation, see Fitzgerald and Lyons (1978).

7. For our purposes, South includes the District of Columbia, the eleven states of the Confederacy, and six border states (Delaware, Kentucky, Maryland, Missouri, Oklahoma, and West Virginia) that had laws requiring separate school systems at the time of the 1954 Brown decision.

Some question exists as to how the division should be made between North and South for purposes of studying school desegregation. Our regional grouping has been based on the traditional de facto/de jure distinctions, assuming that federal intervention operated quite differently in the two areas during the period under investigation. Nonetheless, in some ways the level of school segregation in border states during the early 1970s appeared more comparable to that which existed in the North than in the South. Therefore, we decided to reanalyze the data by including the border states with the North. The results, in our estimation, were not as satisfactory as those we had obtained under the original grouping. Two things stood out. First, the effect of federal intervention on desegregation change diminished in both regions. Second, the final level of explained variance for the change model was lower, again for both regions. Thus, it appears that an analysis in which South includes border states yields better results, given the variables and the models we employ.

Here we might explicitly acknowledge the differences in years for certain variables. For example, district size and percentage black are for 1968. No doubt, in certain districts changes in these variables took place between 1968 and 1974. But overall, the fluctuations that did occur must have largely balanced out among the districts, as the following correla- 
tion coefficients for each of these measures for 1968 and 1974 reveal (North in parentheses):

$$
\begin{array}{ll}
\text { percentage black, } 1968 \text { and } 1974 & r=.97(.98) \\
\text { district size, } 1968 \text { and } 1974 & r=.92(.95)
\end{array}
$$

9. The relationship for northern districts is substantially linear, according to a scatterplot of the data. For the South, of course, virtually no relationship whatever is revealed by a scatterplot.

10. For the 1974 northern desegregation model, $\mathrm{R}^{2}$ drops from .81 to .56 when the 1968 desegregation measure is omitted from the equation.

11. If federal coercion in the South had been constructed to reflect change (say from 1968 to 1974), perhaps the federal impact would have been more prominent. As it stands, federal coercion represents action taken by the national government as of 1974 only. Especially in the South, the coercive measure might be contaminated by pre-1968 enforcement activities. Lack of data for the pre-1968 period, however, prevents us from testing that possibility.

\section{REFERENCES}

ASHER, H. and D. VAN METER (1973) Determinants of Public Welfare Policies: A Causal Approach. Sage Professional Papers in American Politics series 04-009, Volume 1. Beverly Hills, CA: Sage.

BLALOCK, H. M., Jr. (1972) Social Statistics. New York: McGraw-Hill.

CATALDO, E. G. (1975) "Desegregation and white flight." Intergrated Education 13 (January-February): 3-5.

COLEMAN, J. S. (1976) "Recent trends in school integration," in G. Glass (ed.) Evaluation Studies Review Annual. Beverly Hills, CA: Sage.

CRAIN, R., E. KATZ, and D. ROSENTHAL (1969) The Politics of Community Conflict. Indianapolis: Bobbs-Merrill.

DYE, T. R. (1968) "Urban school desegregation: a comparative analysis," Urban Affairs Q. 4 (December): 141-166.

ELlIOT, F. (1964-1974) Patterson's American Education, Volumes 60-70. Mt. Prospect, IL: Educational Directories.

FARLEY, R. (1975) "Racial integration in the public schools, 1967 to 1972: assessing the effect of governmental policies." Soc. Focus 8 (January): 3-26.

FITZGERALD, M. R. and D. R. MORGAN (1977) "Changing patterns of urban school desegregation: a comparative analysis." Amer. Politics Q. 5 (October): 437-463.

FITZGERALD, M. R. and W. LYONS (1978) "Measuring urban school desegregation: a cautionary note." Pol Methodology 5 (4): 511-530.

GILES, M. W. (1975) "Black concentration and school district size as predict ors of school segregation: the impact of federal enforcement." Sociology of Education 48 (Fall): 411-419.

- and T. WALKER (1975) "Judicial policy-making and southern school segregation." J. of Politics 37 (November): 917-936. 
GILES, M. W., E. CATALDO, and D. GATLIN (1975) "White flight and percent black: the tipping point re-examined." Social Sci. Q. 56 (June): 85-92.

GRAY, V. (1973) "Innovation in the states: a diffusion study." Amer. Pol. Sci. Rev. 67 (December): 1174-1185.

KIRBY, D. J. and R. CRAIN (1974) "The functions of conflict: school desegregation in 91 cities." Social Sci. Q. 55 (September): 478-492.

KIRBY, D. J., T. HARRIS, R. CRAIN, and C. ROSSELL (1973) Political Strategies in Northern School Desegregation. Lexington, MA: D. C. Heath.

RODGERS, H., Jr. and C. BULLOCK, III (1976) Coercion to Compliance. Lexington, MA: D. C. HEATH.

SORENSEN, A., K. TAEUBER, and L. HOLLINGSWORTH (1975) "Index of racial residential segregation for 109 cities in the United States: 1940-1970.” Soc. Focus 8 (April): 125-142.

SULLIVAN, J. L. (1971) "Multiple indicators and complex causal models," in H. M. Blalock, Jr. (ed.) Causal Models in the Social Sciences. Chicago: AVC.

TAEUBER, K. E. (1979) "Housing, schools, and incremental segregation effects." Annals 441 (January): 157-167.

-_- and A. TAEUBER (1965) Negroes in Cities. Chicago: AVC.

U.S. Commission on Civil Rights (1973) Title IV and School Desegregation. Washington, DC: Government Printing Office.

(1976) Fulfilling the Letter and Spirit of the Law: Desegregation of the Nation's Schools. Washington, DC: Government Printing Office.

U.S. Department of Health, Education, and Welfare $(1976,1970)$ Directory of Racial and Ethnic Enrollment in Public Schools in Selected Districts. Washington, DC: Government Printing Office.

- - (1973) Federal Assistance to Desegregating School Districts: A Report on Activities From April 1973 to September 1973. Washington, DC: Government Printing Office.

_-__(1972) Federal Assistance to Desegregating School Districts: A Report on Activities From August 1970 to September 1972. Washington, DC: Government Printing Office.

VAN METER, D. S. (1974) "Alternative methods of measuring change: what difference does it make?" Pol. Methodology 1 (Fall): 125-140.

WEGNER, E. L. and J. R. MERCER (1975) "Dynamics of the desegregation process: politics, policies, and community characteristics as factors in change," pp. 123-143 in F. M. Wirt (ed.) The Polity of the School. Lexington, MA: D. C. Heath.

David R. Morgan is Director of the Bureau of Government Research and Professor of Political Science at the University of Oklahoma. His research on state and urban politics has appeared in a number of political science journals. He is the author of Managing Urban America, recently published by Duxbury. Press.

Michael R. Fitzgerald is Assistam Professor of Political Science at the University of Tennessee. Knoxville, and specializes in urban politics. He has published articles on referenda voting. party and candidate images, public school desegregation. and political science departmental productivity. 